\title{
Research on the Necessity and Core Principles of Internet Financial Supervision
}

\author{
Ke Haiqian \\ Nanyang Institute of Technology, Nanyang, Henan, 473000
}

Keywords: Internet Finance, Supervision, Necessity, Core Principles

\begin{abstract}
During the past decades of reform and opening up, China's economy has been developing rapidly. The interest of Internet information technology has made the Internet finance more and more influential in people's lives, and is becoming more and more prominent in the financial field. In this case, the Chinese government also proposed to focus on the construction of Internet banking, but the continuous development of the Internet finance will not only impact the traditional financial market, also bring some pressure for financial regulators. And the Internet environment is complex, involving a large number of users, so it is important for regulation. China's Internet financial regulatory authorities need to build a scientific and perfect Internet financial regulatory system based on the needs of Internet financial development, and continuously enhance the control of Internet financial regulation. This paper analyzes the necessity of strengthening the Internet financial supervision in China, and puts forward the core principles of supervision so as to promote the stable and sustainable development of the Internet.
\end{abstract}

\section{The Connotation of Internet Finance}

In a sense, Internet finance refers to the organic combination of traditional financial industry and the Internet industry. Although the Internet is a virtual environment, it also embodies the characteristics of equality, openness, sharing and collaboration. With its penetration into the traditional financial industry, it has also promoted the transformation of the development mode of the financial industry [1]. To some extent, Internet finance is a financial subdivision industry with internet characteristics. Compared with the traditional finance, the two not only by the use of different media, and whether the user can use the Internet tools, whether financial players familiar with the Internet industry, mode of operation, quality will effect on the Internet financial services have a direct impact; and the Internet Financial greatly reduces the degree of information asymmetry between financial institutions and users [2-3]. The operation is more convenient, lower intermediary costs, thus obtained a rapid development in a short period of time. Further subdivision of the financial sector of the Internet, it can be divided into two modes, one is financial + Internet, namely the traditional financial industry application of Internet innovation on its business and business operations; the other is Internet plus financial is using Internet technology in financial operation, the specific form of network lending platform, raise public network investment platform and the three party payment platform etc.

\section{The Necessity of Internet Financial Supervision}

As a newly emerging thing, the development of Internet finance has been developing rapidly. However, its drawbacks in the development process have increased its necessity for supervision.

First, the Internet financial laws and regulations need to be improved. Although China has issued relevant laws and regulations for the development of Internet financial industry, its development speed is far behind the development speed of Internet finance, resulting in the disconnection between legal provisions and industrial reality [4]. The construction of market economy management in China has gradually become mature, but for the Internet banking supervision is relatively backward, the Internet economy and Internet financial supervision update speed does not match the various problems in its development process uncertain factors will have a direct impact on its development. Provide basic system guarantee of the existing laws and regulations to the 
Internet finance this new thing; and the government financial supervision to the Internet is still relatively weak, all kinds of new Internet emerge in an endless stream of financial crime, the relevant laws and regulations are not for these new types of crime to be standardized. Secondly, the information of consumers and Internet financial institutions is asymmetric [5]. Internet finance involves complex contents. Big data analysis is the technical support for its practical application. In addition, the characteristics of network virtualization lead to a relatively simple understanding of consumers' understanding of Internet finance. Compared with traditional finance, Internet finance is also more risky. If consumers do not understand Internet Finance deeply, it will cause economic losses due to Internet financial risks. And when financial enterprises propagandist financial products, they usually emphasize the income, weaken the risk, and cause the consumers to ignore the risk assessment of the financial products. Thirdly, there are many uncertainties in the virtual nature of the network. The virtual nature of the Internet has increased the uncertainty of Internet finance. For example, Internet security can not guarantee the safety of information inside financial institutions, and make the risk of Internet further increase. Based on the consumer's point of view, the operation when the client may appear all kinds of operation risk; network perspective, in the process of applying data loss, damage, virus attacks, hacker attacks and other problems are Internet financial risk sources [6]. At last, there are great difficulties in the macro regulation of Internet finance. The openness of the Internet makes the development of Internet finance not limited by fixed procedures. Although this is an important factor for its rapid development, it also increases the difficulty of macro control in financial experiments, and directly affects the effect of monetary control. Under the background of the Internet, a large number of social idle funds gathered on the Internet, although the relevant departments can use the network platform for the rational allocation of funds, but in the actual operation of the loan fund and the financial system is out of state, and the central bank deposit reserve system also unable to restrain, it will affect the accuracy of the assessment of monetary supply the amount of.

\section{The Core Principles of Internet Financial Supervision}

\subsection{A combination of various forms of supervision and attention to the consistency of supervision}

Banking supervision is mainly based on the supervision of funds by banks. It adheres to the basic principles of "content is more important than form", and controls the risk of Internet finance through the intervention of banks in order to achieve the goal of protecting consumers' legitimate rights and interests from infringement. In principle, supervision mode, supervision authorities and supervision object is to guide the relationship with the LED, not making too many demands on the object of regulation, the regulatory object will only to achieve regulatory objectives, not to intervene or intervention in the specific business; and in the rules of supervision mode, supervision authorities according to the relevant laws and regulations on financial business procedures, make detailed provisions, and its enforcement [7]. In the Internet financial regulation, we should take the form of regulatory combination of principled supervision and regular regulation. The two complement each other, seeking a balance between maintaining the vitality of the Internet financial market and controlling risks, and ultimately achieving the sustainable development of Internet finance. In addition, we should pay attention to the consistency of supervision and prevent regulatory arbitrage. The so-called regulatory arbitrage refers to the use of fuzzy zones in regulatory standards to reduce regulatory costs, gain excess profits or evade regulatory actions. This behavior is not conducive to fair competition in the market, damaging the effectiveness of regulation, and reducing the credibility of regulators [8]. The service products of Internet Finance include lending and payment similar to traditional financial services. If different regulatory standards are applied to two similar businesses, it will lead to unfair market competition or regulatory arbitrage. Therefore, both Internet and traditional financial businesses must perform the same regulatory standards to ensure consistency between online and offline businesses. 


\subsection{The risk of accepting Internet finance}

The development of Internet has spawned Internet finance, which is totally different from traditional finance. Although the current financial management system has restrained the development of Internet finance to some extent, its essence still belongs to financial activities. The risk factors of financial activities are inevitable and objective, especially the Internet financial industry as a new thing. Its risk probability is far greater than that of the traditional financial industry [9-10]. But not because of the existence of risk on restrict its development so the risk to some extent in the acknowledgement and accept the Internet financial. Of course, such recognition and acceptance do not mean laissez faire development. Instead, we need to effectively supervise the occurrence and development of risks, and control risks within a certain range, and strengthen financial security protection [11]. In order to make the Internet financial customers and the related real economy can get the financial products and financial services in the field of Internet finance. In the process of management, Internet financial enterprises need to focus on reserving a certain space, avoiding more restrictions on product innovation caused by management, and having a very bad effect on the enhancement of overall compatibility. It not only encourages the development and innovation of Internet finance, avoids over supervision, but also ensures the effectiveness of regulation. It guides Internet finance to the right direction of development, avoiding radiation risk and ensuring consumers enjoy better financial services.

\subsection{Protecting consumers}

The high risk of Internet banking increases the necessity to protect consumers of financial products, the Internet is the fundamental purpose of the protection of financial consumer protection rights and interests are not infringed, and protect the interests of consumers behavior and regulation is an important part of the Internet financial products and the protection of consumer behavior is regulated. Specific to the protection of consumers' behavior mainly includes the following parts: first, to reduce the transaction between the consumer and the Internet, continue to protect consumers rights, unable to guarantee the validity of the financial information of the financial consumer Internet transactions, it will affect and infringe the rights and interests of the consumers, so some trading patterns formed between try to control the operation of shareholders and financial institutions, to avoid the occurrence of illegal occupation, in order to protect the interests of consumers [12]. Secondly, we should coordinate the relationship between Internet financial institutions and related securities transactions, improve transaction efficiency of financial transactions by means of strict management, reduce operational risks, prevent customers' funds from being misappropriated, and maximize the safety of customers' funds. Thirdly, we should establish a risk control mechanism and set up a special risk management department. Apart from coordinating the main responsibilities of various departments, we should also implement a risk management system to enhance the safety management of the computerized management system and ensure the effective management of various facilities run. Finally, a transparent management system is established. Social donation can help more people in need, to raise public awareness of responsibility and social responsibility, and now the network will release a lot of fundraising, donations and other information, consumers make a donation according to the channels and methods of Internet publishing, but donations after the whereabouts of the money, this is not a reasonable regulation. It is necessary to establish a transparent system for network management of capital flows, such as the real name system to record the user's record in each donation system of professional; specific contributions tracking process, ensure the inflow of funds into the hands of the needy; by means of logistics tracking, to ensure the public monitoring of their own funds to etc..

\section{Conclusions}

In short, the development of Internet technology has promoted the development of Internet financial industry, and formed a specific financial mode. People's consumption concept has also undergone great changes. Although there are some risks in the use of Internet finance, some 
investors are desperate for high returns, which further promote the development of Internet financial industry. Therefore, the government departments should strengthen the supervision of Internet banking, improve the existing laws and regulations, the uncertainty and risk of Internet financial investment in the lowest, the maximum extent to ensure the legitimate rights and interests of consumers, improve internet financial management level, so that consumers can enjoy a better quality of Internet financial services, to achieve the healthy development of the Internet the financial industry.

\section{References}

[1] Mario T, Jan K. Fundamental Principles of Financial Regulation and Supervision[J]. Working Papers, 2014, 10(1):59-68.

[2] ISCR. Republic of Moldova: Financial Sector Assessment Program-Detailed Assessment of Observance on the Basel Core Principles for Effective Banking Supervision[J]. Imf Staff Country Reports, 2014, 16(71):1.

[3] Vries F D. How Can Principles-Based Regulation Contribute to Good Supervision?[M]// Financial Supervision in the 21st Century. Springer Berlin Heidelberg, 2013:165-183.

[4] ISCR. Singapore: Detailed Assessment of Compliance on the Basel Core Principles for Effective Banking Supervision [J]. Imf Staff Country Reports, 2013(3):218-222.

[5] ISCR. Malaysia: Publication of Financial Sector Assessment Program DocumentationDetailed Assessment of Basel Core Principles for Effective Banking Supervision[C]// International Monetary Fund, 2013:568-580.

[6] Bank W. Financial Sector Assessment Program Update: India - Basel Core Principles for Effective Banking Supervision [J]. World Bank Other Operational Studies, 2013(3):467-530.

[7] Cavelaars P, De Haan J, Hilbers P, et al. Challenges for financial sector supervision [J]. Dnb Occasional Studies, 2013, vol.11/no.6.

[8] Nachane D M. Monetary Policy, Financial Stability and Macro-prudential Regulation: An Indian Perspective [M]// Market, Regulations and Finance. Springer India, 2014:17-39.

[9] Lucia Quaglia. Financial regulation and supervision in the European Union after the crisis [J]. Journal of Economic Policy Reform, 2013, 16(1):17-30.

[10] Department M C M. Bosnia and Herzegovina: Financial Sector Assessment Program - Banking Sector Supervision Core Principles Implementation Update-Technical Note [J]. Imf Staff Country Reports, 2015, 15(214):1.

[11] Kellermann A J, Haan J D, Vries F D. Financial Supervision in the 21st Century[J]. 2013, 3(2):55-63.

[12] ISCR. Belgium: Detailed Assessment of Compliance with the Basel Core Principles for Effective Banking Supervision [J]. Imf Staff Country Reports, 2013(3):218-222. 